\title{
Effect of 2 different premilking teat sanitation routines on reduction of bacterial counts on teat skin of cows on commercial dairy farms
}

\author{
C. Baumberger, J. F. Guarín, and P. L. Ruegg ${ }^{1}$ \\ Department of Dairy Science, University of Wisconsin, Madison 53706
}

\begin{abstract}
Premilking teat sanitation reduces the load of bacteria on teat skin before milking and it is a fundamental practice used to ensure collection of high-quality milk. The objective of this study was to compare reduction in bacterial populations of teat skin after premilking preparation using either predipping with $0.5 \%$ iodine followed by drying (conventional; CONV) or using a semiautomated teat scrubber that uses chlorine dioxide (TS; FutureCow, Longwood, FL). Ten farms currently using a commercial teat scrubber system were enrolled. Cows ( $\mathrm{n}=40$ per farm) were assigned to CONV ( $\mathrm{n}=$ $198)$ or TS $(\mathrm{n}=196)$ premilking udder preparation. Teat skin swabs were collected before and after udder preparation and analyzed for total bacterial count (TBC), Streptococcus spp., Staphylococcus spp., and gram-negative bacteria (GNB). Reduction (RED) of each bacterial group was defined as the difference in the number of bacteria measured before and after udder preparation. Before udder preparation, Staphylococcus spp. (15,036 cfu/mL) and Streptococcus spp. (12,621 $\mathrm{cfu} / \mathrm{mL}$ ) were the most numerous microflora. Gramnegative bacteria were less numerous $(1,538 \mathrm{cfu} / \mathrm{mL})$. A significant treatment by farm interaction was identified for RED of all bacterial counts. Compared with teats prepared using TS, teats prepared using CONV preparation had greater RED of TBC on 3 farms, of Streptococcus spp. on 2 farms, and of Staphylococcus spp. on 1 farm. On all other farms, RED in TBC, Streptococcus spp., and Staphylococcus spp. did not differ based on teat preparation method. Use of TS resulted in greater RED of GNB of teats on 3 farms, but RED in GNB was greater for teats cleaned by CONV on 1 farm; for the other 6 farms, RED of GNB did not differ between methods. For all bacterial counts, an effect of chlorine dioxide concentration used in the teat scrubber was observed. Results from this study suggest both CONV and TS can effectively reduce bacterial
\end{abstract}

Received June 23, 2015.

Accepted December 27, 2015.

${ }^{1}$ Corresponding author: plruegg@wisc.edu counts, but farm conditions and management practices can have a significant effect on the effectiveness of teat disinfection.

Key words: premilking udder preparation, teat, hygiene, milking

\section{INTRODUCTION}

Use of an efficient method of premilking teat sanitation is an important aspect of producing high-quality milk (Pankey, 1989). The potential contribution of teat skin bacteria to bulk milk bacterial counts is based on bacterial populations of teat skin and efficacy of premilking teat sanitation. Soiled teats are an important source of contamination and ineffective sanitation can result in increased bacterial counts of bulk milk (Galton et al., 1982; Bramley and McKinnon, 1990; Murphy, 1997). Effective premilking teat sanitation reduces the number of bacteria on teat skin, thus decreasing bacterial contamination of milk and improving milk quality (Galton et al., 1986; Jayarao and Wolfgang, 2003).

Bacterial contamination of teat skin can also affect udder health. The rate of new IMI has been shown to increase with increasing numbers of bacteria on teat ends (Neave et al., 1969). Mastitis pathogens enter the mammary gland through the teat canal (Bramley and McKinnon, 1990), and it has been well established that reducing teat end exposure to microorganisms can result in reduced incidence of IMI (Pankey, 1989). Premilking teat sanitation is therefore an important component of mastitis control programs.

Various methods of premilking teat sanitation have been studied. Some researchers have evaluated the effectiveness of different methods of premilking sanitation with an emphasis on reducing the rate of IMI (Galton et al., 1988; Ruegg and Dohoo, 1997; Oliver et al., 2001). Other researchers have described the effectiveness of teat sanitation in reducing bacterial contamination of teat skin by enumerating bacterial populations of milk or teat skin (Galton et al., 1986; Gibson et al., 2008; Gleeson et al., 2009). More than $30 \mathrm{yr}$ ago, effective procedures for teat sanitation were described and continue to be recommended (Galton et al., 1982, 1984, 1986). 
To decrease bacterial populations, teat skin should be adequately cleaned and dried. As compared with other methods of premilking sanitation, the use of predipping followed by drying teats has been shown to result in more effective teat skin sanitation (Ingawa et al., 1992; Elmoslemany et al., 2010). The effectiveness of various disinfectants for prevention of new IMI has been extensively investigated (Pankey et al., 1987; Oliver et al., 1993a,b; Ruegg and Dohoo, 1997). Researchers have demonstrated variable efficacy depending on the etiology and type of disinfectant. The effect of predipping on reducing IMI is more successful for those caused by environmental pathogens as compared with contagious pathogens (NMC, 1995).

As the size of dairy farms increases, the use of automation to perform many milking tasks is increasing. During the milking process, use of automation ranges from partial (use of automatic cluster removers) to complete (use of completely automatic milking systems). Recently, automated premilking teat preparation systems for use in conventional parlors have been developed. Adoption of automated teat preparation systems usually involves alteration of the premilking work routine and often involves changes in the type of premilking teat disinfectant. Whereas manufacturers have recommendations for how to use their systems, no scientific studies have documented the effectiveness of automatic teat preparation systems used in conventional parlors. The objective of the current study was to compare the reduction in bacterial populations of teat skin after premilking preparation using either predipping with $0.5 \%$ iodine followed by drying (conventional) or using a semiautomated teat scrubber that uses chlorine dioxide (FutureCow, Longwood, FL, http://www.futurecow. com/products/teat-scrubber/).

\section{MATERIALS AND METHODS}

\section{Farm Selection and Premilking Udder Preparation}

Farms were eligible to participate if they were currently using the selected commercial teat scrubber system. Farms were contacted from a list $(\mathrm{n}=19)$ of Wisconsin customers provided by the company that manufactures the teat scrubber and the first farms $(\mathrm{n}=$ 10) willing to participate were enrolled. Enrolled farms were visited once during milking between November 8 , 2013, and March 3, 2014.

Two different premilking routines were evaluated: conventional premilking udder preparation using $0.5 \%$ iodine as disinfectant (CONV) and premilking udder preparation using a commercial teat scrubber system that uses chlorine dioxide as disinfectant (TS). Therefore, premilking routines evaluated in our study differ not just in the delivery method of the disinfectant solution but also in the disinfectant solution applied.

At each farm, 40 cows were selected to participate in the experiment based upon entry to stalls that were allocated to the experiment. On each farm that used a linear parlor $(\mathrm{n}=9)$, cows milked in the first and second stall of each group of cows entering the parlor were enrolled. Within each group of cows entering the parlor, enrolled cows on the right side of the parlor (n $=20$ ) were assigned to CONV whereas enrolled cows on the left side of the parlor $(\mathrm{n}=20)$ were assigned to udder preparation using TS. One of the farms had a rotary milking parlor. In this instance, 20 cows in groups of 2 cows prepared together were assigned to CONV routine and then 20 cows in groups of 2 cows prepared together were assigned to TS routine. Cows that were identified by university researchers or farm personnel with any signs of clinical mastitis (abnormal milk or swollen quarter), or milking with less than 4 functional quarters were excluded. Premilking preparation using TS was performed by milking technicians of each farm. On all farms, CONV was performed by the same member of the research team. Conventional premilking preparation consisted of (1) forestripping 3 streams of milk per quarter, (2) applying $0.5 \%$ iodine predipping solution using a dip cup, (3) allowing at least $30 \mathrm{~s}$ of contact time, (4) drying with a cloth towel, and (5) attaching the milking unit. Preparation using the TS consisted of applying disinfectant solution and drying teats using the commercial teat scrubber system. Briefly, the TS consists of a unit that contains 3 rotating brushes. When the milking technician pulls the trigger, the brushes rotate and a chlorine dioxide sanitizing solution is dispensed. The TS is applied to each teat as a cleaning step, and then a second application of the TS is generally performed using just rotating brushes (without disinfectant solution) with the objective of removing moisture from teats. For cows assigned to the TS routine, forestripping was performed by milking technicians before teat sanitation on 8 farms. Farms $\mathrm{C}$ and $\mathrm{G}$ did not forestrip; therefore, the milk of cows assigned to the TS on these farms was not evaluated.

The time spent to clean the teats (TPREP) was recorded for both CONV and TS. For TS, TPREP was defined as the time that the milking technician was using the TS to sanitize and remove moisture from all 4 teats. For CONV, TPREP was defined as the time from application of predip of the first teat until drying the last teat (including the contact time). The use of additional premilking procedures performed before the use of the TS, such as forestripping and prewiping, were recorded for each farm (but not included in TPREP), as well as the concentration of the chlorine dioxide solution. The concentration of chlorine dioxide $(\mathbf{C D}, \mu \mathrm{L} / \mathrm{L})$ 
Table 1. Dilutions used to enumerate total bacterial count (TBC), gram-negative noncoliform bacteria, coliforms, and Streptococcus spp. and Staphylococcus spp. counts in teat swabs collected before (PRE) and after (POST) premilking udder preparation

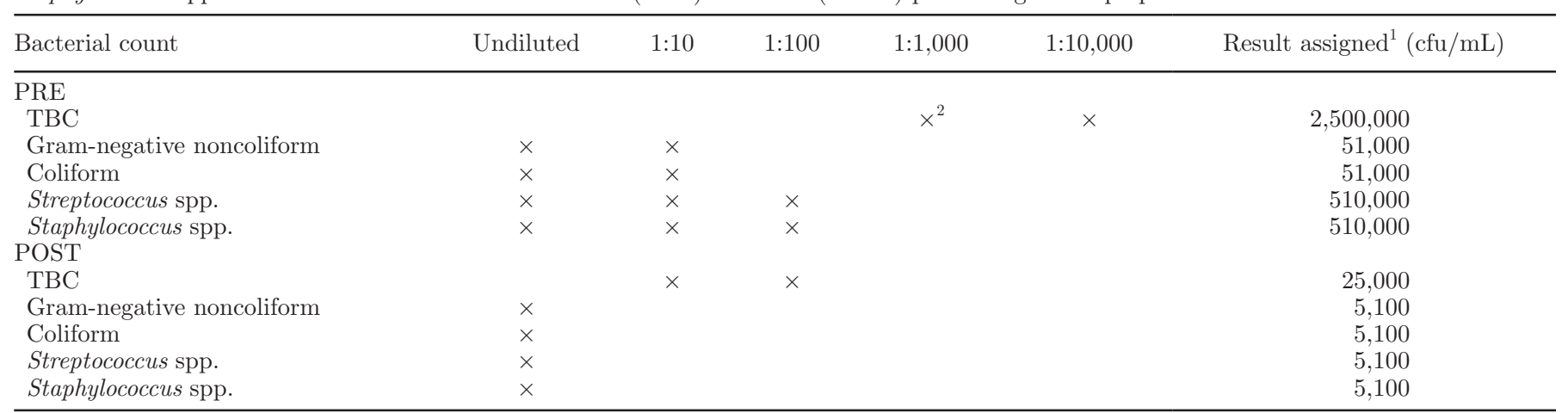

${ }^{1}$ Result assigned when the greatest dilution contained $>250$ colonies in $1 \mathrm{~mL}$ (TBC) or $>50$ colonies per inoculum of $10 \mu \mathrm{L}$ (gram-negative noncoliform bacteria, coliforms, Streptococcus spp. and Staphylococcus spp.). For gram-negative noncoliform bacteria, coliforms, Streptococcus spp., and Staphylococcus spp., the result assigned resulted from multiplying 51 by 100 by the dilution factor of the greatest dilution tested. For TBC, the result assigned resulted from multiplying 250 by the dilution factor of the greatest dilution tested.

${ }^{2}$ Dilutions tested.

used in the TS was titrated using a chlorine dioxide test kit (GEA Farm Technologies, Naperville, IL). Chlorine dioxide was delivered to each TS unit in the parlor from a single blending system providing each TS unit with the same concentration. The concentration of chlorine dioxide was titrated on each farm immediately after collection of all teat swab samples.

\section{Collection of Samples}

Before any of the steps of the premilking routine was performed, a teat skin swab was collected from the left fore and right rear teats (PRE) and after the premilking routine was completed (before unit attachment), the same university researcher collected a teat skin swab from the right fore and left rear teats (POST). In both instances (PRE and POST), both teats were swabbed using the same swab. Teat swabs were collected using a rolled gauze swab $(10.2 \times 10.2 \mathrm{~cm})$ moistened in buffered peptone water (Becton, Dickinson and Company, Sparks, MD) by wiping one side of the teat barrel from top to bottom, passing over the teat end and wiping the other side of the teat barrel from top to bottom. Swabs were placed in $4 \mathrm{~mL}$ of buffered peptone water, immediately cooled, and transported on ice to the University of Wisconsin, Madison Milk Quality laboratory. Swabs were cultured fresh if processed within approximately $12 \mathrm{~h}$ after collection (3 farms) but they were frozen (from 2 to $7 \mathrm{~d}$ ) if microbiological analysis could not be performed within $24 \mathrm{~h}$ (7 farms). On each farm, samples belonging to cows assigned to CONV and TS were handled in the same manner.

After all teat swabs were collected, bedding samples were collected from all pens that contained enrolled cows. The bedding samples were mixed at the laboratory and the composite bedding sample was processed.

\section{Bacteriological Culture}

Teat Swabs. Teat swabs were analyzed for total bacterial count (TBC), gram-negative noncoliform bacteria, coliforms, Streptococcus spp., and Staphylococcus spp. A wide range of dilutions were tested for the first farm to determine the most appropriate dilutions to quantify bacteria. Based on the distribution of results that fell outside of the lowest and upper detection limit, dilutions were determined so that the majority of the samples would fall in the countable range (Table 1).

At the laboratory, swabs were squeezed and the liquid transferred to a sterile vial. Sterile tubes and buffered peptone water were used to make four 10-fold serial dilutions from 1:10 to 1:10,000 for the PRE samples and 1:10 and 1:100 dilutions for the POST samples. One milliliter of 1:1,000 and 1:10,000 dilutions (PRE) and of 1:10 and 1:100 dilutions (POST) were inoculated onto Petrifilm Total Aerobic Count plates (3M, St. Paul, $\mathrm{MN}$ ), incubated for $48 \mathrm{~h}$ at $32^{\circ} \mathrm{C}$, and then counted using the Petrifilm Plate Reader (3M). As recommended by the manufacturer, plates have a counting range between 25 and 250 colonies. Based on the dilutions tested, samples below the lowest limit detection were assigned 25,000 and $250 \mathrm{cfu} / \mathrm{mL}$ to PRE and POST samples, respectively. Samples above the upper limit detection were assigned 2,500,000 and 25,000 cfu/mL to PRE and POST samples, respectively (Table 1).

Gram-negative noncoliform bacteria, coliforms, Streptococcus spp., and Staphylococcus spp. were counted using a microbiological technique adapted from Hogan 
et al. (1989). For these bacterial counts, the undiluted POST sample was used. Phosphate-buffered saline solution was used to make 1:10 and 1:100 dilutions in a microtiter plate for the PRE samples. MacConkey agar (Becton, Dickinson and Company) was used to enumerate gram-negative noncoliform bacteria and coliforms. All lactose-fermenting (red or pink) colonies were defined as coliforms, whereas colorless colonies were defined as gram-negative noncoliform bacteria. Edwards modified agar (Oxoid Ltd., Basingstoke, UK) containing 5\% bovine plasma and Baird Parker agar (Becton, Dickinson and Company) were used to enumerate Streptococcus spp. and Staphylococcus spp., respectively. Depending on genera, a variety of dilutions were used (Table 1). For all bacterial counts, the technique consisted of plating 4 inoculums of $10 \mu \mathrm{L}$ of each dilution onto half of the agar plate. The plates were incubated for $36 \mathrm{~h}$ at $37^{\circ} \mathrm{C}$. After incubation, the average colony-forming units of the 4 inoculums was multiplied by 100 and by the dilution factor. When multiple dilutions were tested, the plate containing between 1 and 50 colonies per inoculum was counted. For all bacterial counts, when colonies in an inoculum could not be individualized, it was considered to contain $>50$ colonies. For all bacterial counts of POST samples, as the undiluted sample was plated, $5,100 \mathrm{cfu} / \mathrm{mL}$ was assigned when colonies could not be individualized. Based on the dilutions, when too many colonies were in the most diluted PRE sample, $51,000 \mathrm{cfu} / \mathrm{mL}$ was assigned to gram-negative noncoliform bacteria and coliforms (because for these bacterial counts the greatest dilution tested was $1: 10$ ) and $510,000 \mathrm{cfu} / \mathrm{mL}$ was assigned to Streptococcus spp. and Staphylococcus spp. (because the greatest dilution tested was 1:100 for these bacterial counts; Table 1). Total gram-negative bacteria (GNB) was defined as the sum of gram-negative noncoliform bacteria and coliforms.

Bedding Samples. Bedding samples were analyzed for gram-negative noncoliform bacteria, coliforms, Klebsiella spp., Streptococcus spp., and Staphylococcus spp. using the microbiological technique as described by Hogan et al. (1989).

\section{Statistical Analysis}

Statistical analysis were performed using SAS version 9.3 (SAS Institute Inc., Cary, NC) and statistical significance was defined at $\leq 0.05$. Bacterial counts were transformed to base-10 logarithm for analysis. For all models, all multiple comparisons were performed using a $P$-value adjusted by Tukey.

The hypothesis that no difference existed in the number of Streptococcus spp., Staphylococcus spp., and GNB cultured from different types of bedding (sand, biosolids, other) was tested using 3 separate ANOVA models (one per each bacterial count) with PROC GLM. The experimental unit of this analysis was farm $(\mathrm{n}=10)$.

The hypothesis that no difference was present in number of Streptococcus spp., Staphylococcus spp., and GNB in PRE samples based on bedding types (sand, biosolids, other) was tested using 3 mixed models (one per each bacterial count) with PROC MIXED. The experimental unit of this analysis was cow $(\mathrm{n}=394)$. To account for the clustering of cows within farms, farm was included in the models as a random effect.

The hypothesis that there was no difference among the numbers of Streptococcus spp., Staphylococcus spp., and GNB bacteria in teat swabs cultured from PRE samples was tested using a mixed model with PROC MIXED. Likewise, mean differences in the number of Streptococcus spp., Staphylococcus spp., and GNB bacteria in POST samples were tested in a separate mixed model using PROC MIXED. The experimental unit of these analyses was cow $(\mathrm{n}=394)$. In both models, to account for the clustering of cows within farms, farm was included as a random effect.

The hypothesis that no differences existed in number of Streptococcus spp., Staphylococcus spp., and GNB in teat swabs of PRE samples based on treatment (TS, CONV) was tested using a mixed model with PROC MIXED. The experimental unit of this analysis was cow $(\mathrm{n}=394)$. To account for the clustering of cows within farms, farm was included in the models as a random effect.

The hypothesis that the proportion of noncountable results of bacterial culture of teat swabs (TBC, Streptococcus spp., Staphylococcus spp., and GNB) of PRE was independent of treatment (CONV and TS) was tested using Chi-squared analysis performed with PROC FREQ.

Reduction (RED) in bacteria of teat skin was calculated as the difference between the $\log _{10}$ values of POST and PRE, with negative values indicating a decrease in bacterial counts. To test the hypothesis that no difference existed in RED of each count (TBC, Streptococcus spp., Staphylococcus spp., and GNB) based on treatment (TS, CONV), 4 separate ANOVA models (one for each bacterial count) were created using PROC GLM. These models included RED as outcome variable and treatment (CONV and TS), farm, and treatment by farm interaction as explanatory variables. Results of teat swabs of cows was the experimental unit for these models.

For premilking udder preparation using TS, TPREP was defined as the time that the milker was using the TS to sanitize and remove moisture from all 4 teats. For CONV, TPREP was defined as the time from applica- 
tion of predip of the first teat until drying the last teat. Standard deviations for TBC of POST samples and for TPREP by farm were compared using Levene's test (SAS Institute Inc.). Within each treatment group (TS, CONV), PROC GLM was used to test the hypothesis that no variability in TPREP would be found for each of the treatments among farms. Two ANOVA models were created (one for cows prepared using CONV and one for cows prepared using TS). In both instances, TPREP was the outcome variable and farm was offered to the model as explanatory variable. The experimental unit of this analysis was cow $(\mathrm{n}=198$ for the analysis of CONV and $n=196$ for the analysis of TS).

For teats prepared using TS, the hypotheses that no effect of TPREP or PPM on RED existed was evaluated for each bacterial count (TBC, Streptococcus spp., Staphylococcus spp., and GNB) using farm $(\mathrm{n}=10)$ as the experimental unit. Four multiple linear regression models (one for each bacterial count) were built using PROC GLM. The outcome variable was RED, and TPREP and CD were used as continuous explanatory variables. Time spent to clean teats on 1 cow and RED were measured at cow level; however, CD was measured at farm level. For this reason, the arithmetic means of RED for each bacterial count and the arithmetic mean of TPREP were calculated for each farm and used in this model.

\section{RESULTS}

\section{Farms Characteristics and Milking Routines}

Participating farms $(\mathrm{n}=10)$ ranged in size from 280 to 2,450 lactating cows with an average daily milk production per cow of $39 \mathrm{~kg}$ ( range $=32.2$ to $44.0 \mathrm{~kg}$; Table 2 ). All cows were milked 3 times a day. At the time that the experiment was performed, bulk milk SCC of enrolled farms ranged from 108,000 to 263,000 cells $/ \mathrm{mL}$ and bulk milk TBC ranged from 2,000 to 10,000 cfu/ $\mathrm{mL}$ (Table 2). Cows were housed in freestalls containing sand $(\mathrm{n}=5)$, biosolids $(\mathrm{n}=3)$, cocoa hulls $(\mathrm{n}=$ $1)$, or sawdust $(\mathrm{n}=1)$. Farms had parallel $(\mathrm{n}=8)$, herringbone $(\mathrm{n}=1)$, or rotary parlors $(\mathrm{n}=1)$ and the number of milking units per farm ranged from 12 to 80 . For linear parlors, the number of milking units supplied by a TS unit ranged from 10 to 24 (Table 2). The rotary parlor used a single TS unit per 80 milking units. All farms were currently using TS but varied in use of other premilking procedures. Three farms gently and rapidly prewiped teats using a dry towel as the first step of the premilking routine. This step was performed before beginning teat disinfection (before application of the teat disinfectant) and was performed using one dry towel on multiple cows. These farms had a sequential premilking routine and cows were prepared in groups of 12 (farm A), 5 (farm D), and 10 cows (farm F) and the same dry cloth towel was used to prewipe teats of cows that were prepared together. Forestripping was performed before teat sanitation on 8 of 10 farms.

For cows in the TS group, the overall mean TPREP was $11.5 \mathrm{~s}$ (range $=2.7$ to $24.3 \mathrm{~s}$ ) and varied among farms $(P<0.01)$. The concentration of the CD solution used in the TS ranged from 50 to $850 \mu \mathrm{L} / \mathrm{L}$ (Table 2). For cows in the CONV group, the overall mean TPREP (including $30 \mathrm{~s}$ contact time for the predip) was $47.0 \mathrm{~s}$ $(\mathrm{SD}=19.2)$ and varied among farms $(P<0.01)$. Less time was spent to clean teats of cows prepared using TS (TPREP of $11.5 \mathrm{~s} \pm 0.3$ ) as compared with cows prepared using CONV (47.0 s $\pm 1.4 ; P<0.01)$. Standard deviations for TPREP were greater for CONV in comparison to TS in all farms $(P=0.03)$.

For 8 farms, (A, B, C, D, F, H, I, and J), no significant difference in the SD of POST TBC was observed between the CONV and TS treatments, indicating an equal consistency for both preparation treatments in cleaning teats on these farms. However, greater variation was observed for CONV for farm $\mathrm{E}$ and for TS in farm $\mathrm{G}(P<0.01)$.

The number of Staphylococcus spp. and GNB in bedding did not vary among bedding types $(P=0.13)$; however, a tendency was noted for greater numbers of Streptococcus spp. in sand bedding as compared with biosolids $(P=0.08)$. The number of Staphylococcus spp., Streptococcus spp., and GNB before udder preparation on teats of cows did not differ among bedding types $(P=0.19)$.

\section{Bacterial Counts of Teat Swabs}

Of 400 cows enrolled in the study, 200 cows were assigned to CONV routine and 200 to TS routine. Data were lost from 2 PRE samples of cows assigned to CONV and from 2 PRE and 2 POST samples of cows assigned to TS, leaving 198 and 196 cows assigned to CONV and TS, respectively. Variation in all bacterial counts of PRE samples was observed among farms $(P$ $<0.01$; Table 3).

For PRE, the percentage of samples that exceed the upper detection limit was $26.4(>2,500,000 \mathrm{cfu} / \mathrm{mL}$; n $=104 \mathrm{TBC}), 4.6$ (>510,000 cfu/mL; $\mathrm{n}=18$ Streptococcus $\mathrm{spp}.), 10.7$ (>510,000 cfu/mL; $\mathrm{n}=42$ Staphylococcus $\mathrm{spp}$.), and $18.8 \%$ (>51,000 cfu/mL for coliforms or $>51,000$ for gram-negative noncoliforms; $\mathrm{n}=74 \mathrm{GNB}$ ). For POST, the percentage of samples that exceed the upper detection limit was $25.6(>25,000 \mathrm{cfu} / \mathrm{mL} ; \mathrm{n}=$ $101 \mathrm{TBC}), 10.4$ (>5,100 cfu $/ \mathrm{mL} ; \mathrm{n}=41$ Streptococcus spp.), 17.8 (>5,100 cfu $/ \mathrm{mL} ; \mathrm{n}=70$ Staphylococcus spp.), and $4.8 \%$ (>5,100 cfu/mL for coliforms or 


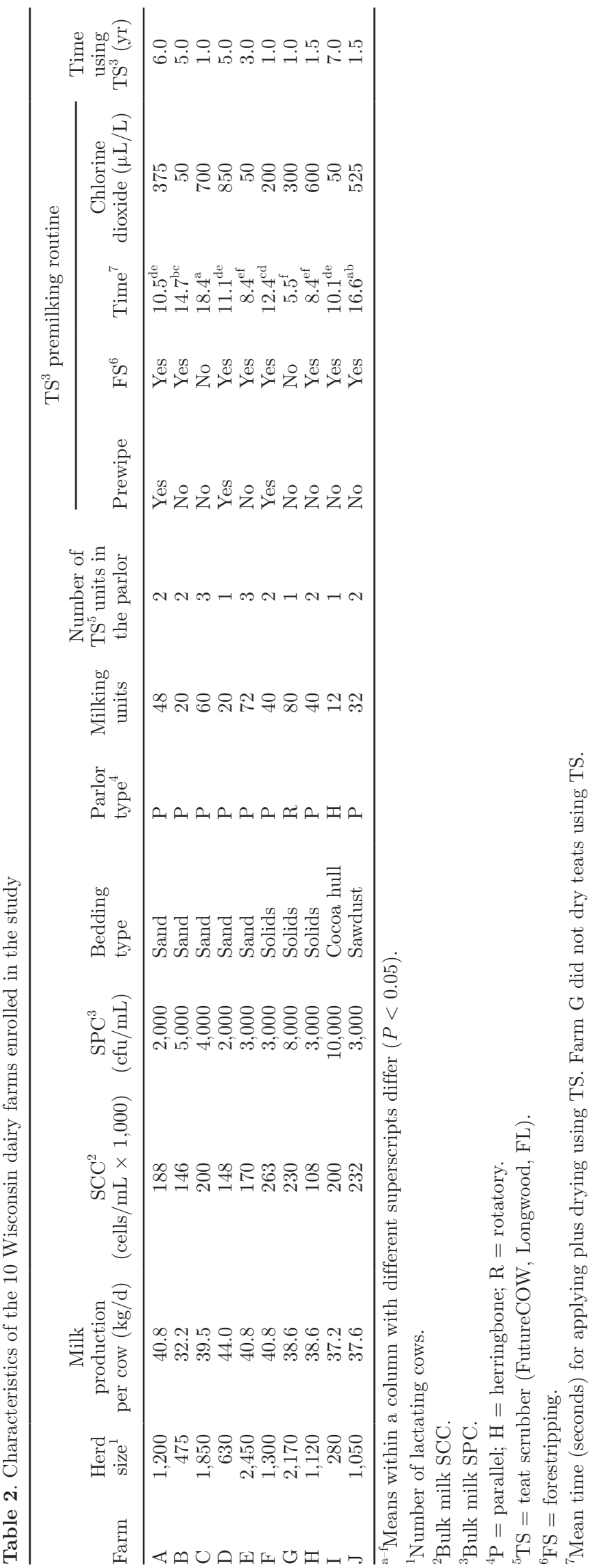

$>5,100$ for gram-negative noncoliforms; $\mathrm{n}=18$ GNB). Bacterial counts in PRE samples did not differ between CONV and TS $(P=0.48$; Table 4$)$. For all bacterial groups assessed, the proportion of PRE results that were not countable was independent of treatment group $\left(\chi^{2}=1.67, P=0.20\right)$.

Overall, no difference was noted in the number of Staphylococcus spp. (mean \pm SEM; $4.18 \pm 0.05 \mathrm{log}$ units) and Streptococcus spp. (4.10 $\pm 0.05 \log$ units) cultured from PRE samples $(P=0.49)$, but fewer GNB were recovered $(3.19 \pm 0.07 \log$ units; $P<0.01)$. Overall, the number of bacteria cultured from POST samples was least for GNB $(0.92 \pm 0.06 \log$ units; $P<$ 0.001) compared with the number of Streptococcus spp. and Staphylococcus spp. In this instance, the number of Staphylococcus spp. (2.07 \pm 0.07 log units) was greater than the number of Streptococcus spp. $(1.86 \pm 0.07 \mathrm{log}$ units; $P<0.01$; Figure 1). Overall RED in bacterial counts were $-2.11,-2.24,-2.10$, and $-2.27 \log$ units for TBC, Streptococcus spp., Staphylococcus spp., and GNB, respectively.

\section{Comparison of Udder Preparation Treatments}

For all bacterial counts, significant main effects (treatment and farm) and 2-way interactions (treatment by farm) were identified for RED (Table 5). Due to the significant interaction, only the means of the interaction terms were contrasted. On most farms, no differences in RED between treatments were observed for most bacterial counts. However, RED in TBC, Streptococcus spp., and Staphylococcus spp., were greater for teats prepared using CONV on 3, 2, and 1 farms, respectively $(P<0.01$, Table 5$)$. In contrast, RED in GNB was greater for teats prepared using TS on 3 farms $(P$ $=0.02)$, whereas in 1 farm RED in GNB was greater for teats prepared using CONV $(P<0.01$; Table 5$)$. Least squares means of RED in TBC were -2.26 and $-1.97 \log$ units for CONV and TS, respectively, and ranged from -1.58 to $-2.55 \mathrm{log}$ units among farms. Least squares means of RED in Streptococcus spp. were -2.34 and $-2.14 \log$ units for CONV and TS, respectively, and ranged from -1.40 to -2.88 log units among farms. Least squares means of RED in Staphylococcus spp. were -2.23 and $-1.97 \log$ units for CONV and TS, respectively, and ranged from -1.45 to $-3.17 \log$ units among farms. Least squares means of RED in GNB were -2.12 and $-2.43 \log$ units for CONV and $\mathrm{TS}$, respectively, and ranged from -0.08 to $-3.30 \mathrm{log}$ units among farms.

For teats prepared using TS, the greatest RED in bacterial counts was observed for GNB $(P=0.02$; Figure 2). For teats prepared using CONV, a tendency of greater RED was noted for Streptococcus spp. compared 
EFFECT OF 2 PREMILKING ROUTINES

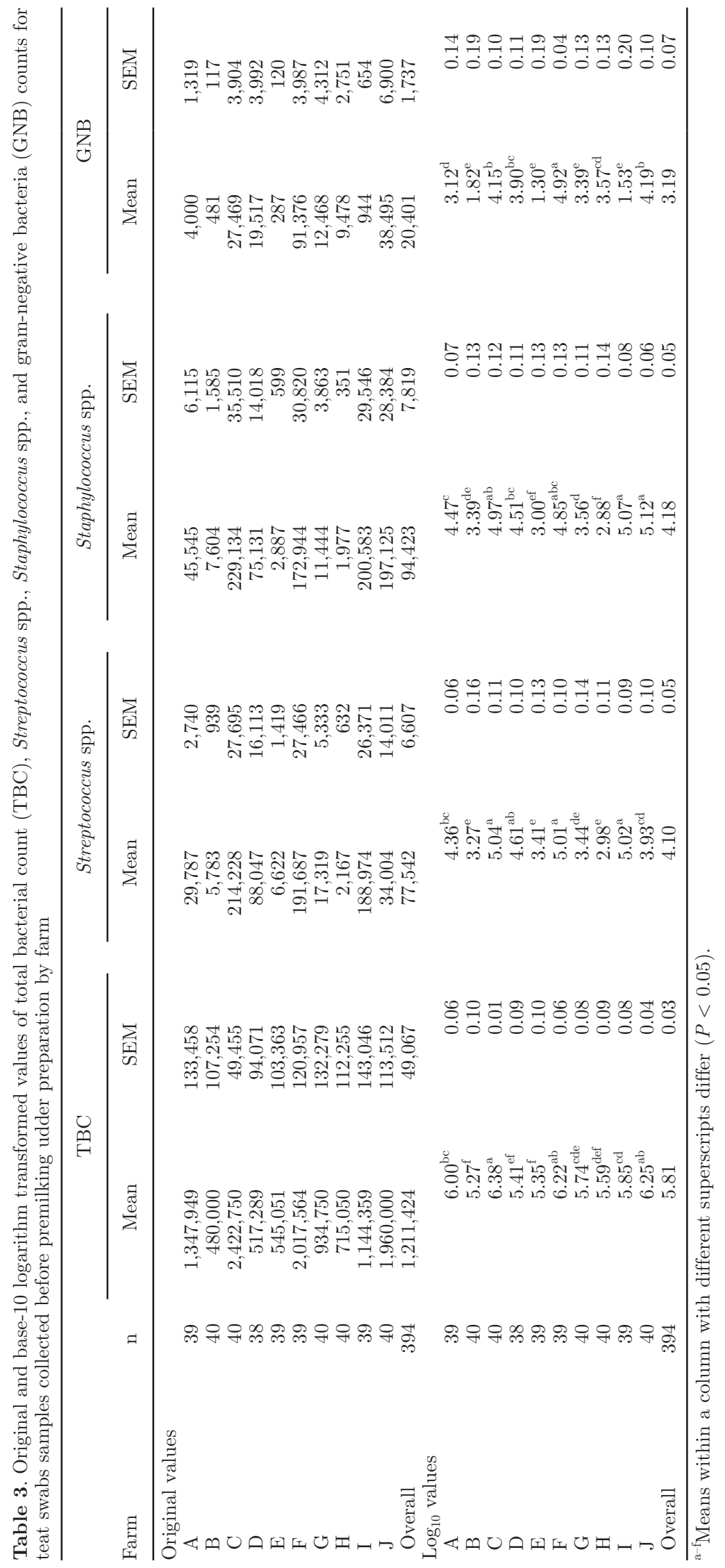


Table 4. Least squares means of total bacterial count (TBC), Streptococcus spp., Staphylococcus spp., and gram-negative bacteria (GNB) counts on teat swabs collected before udder preparation by premilking udder preparation treatment

\begin{tabular}{lccccc}
\hline Treatment $^{1}$ & $\mathrm{n}$ & TBC & Streptococcus spp. & Staphylococcus spp. & GNB \\
\hline CONV & 198 & 5.80 & 4.08 & 4.19 & 3.18 \\
TS & 196 & 5.81 & 4.13 & 4.17 & 3.20 \\
$P$-value & & 0.96 & 0.48 & 0.74 & 0.77 \\
\hline
\end{tabular}

${ }^{1}$ Preparation treatments: $\mathrm{CONV}=$ conventional; $\mathrm{TS}=$ teat scrubber (FutureCOW, Longwood, FL).

with GNB $(P=0.09)$, whereas RED in Staphylococcus spp. did not differ from Streptococcus spp. or GNB $(P$ $=0.49 ;$ Figure 2 ).

For teats prepared using TS, an effect of TPREP on RED was not identified for any bacterial count; however, a significant effect of CD on RED of all bacterial counts was observed (Table 6). For every $100 \mu \mathrm{L} / \mathrm{L}$ increase in the concentration of chlorine dioxide, the absolute value of RED increased by $0.09 \log$ units for TBC $(P=0.02)$, by $0.16 \log$ units for Streptococcus spp. $(P<0.01)$, by $0.18 \log$ units for Staphylococcus spp. $(P<0.01)$, and by $0.33 \log$ units for GNB $(P<$ $0.01)$.

\section{DISCUSSION}

This study was conducted on farms that were currently using the TS technology evaluated in this study. The manufacturer of the TS provided partial funding and a list of potentially eligible Wisconsin dairy farms. From this list, researchers independently enrolled farms and conducted the study without further interaction with the manufacturer. As researchers did not control the initial sampling frame, it is likely that the enrolled farms had been judged by the manufacturer to be successfully using the TS system for at least 1 yr. Thus, results of our study may not be applicable to herds that

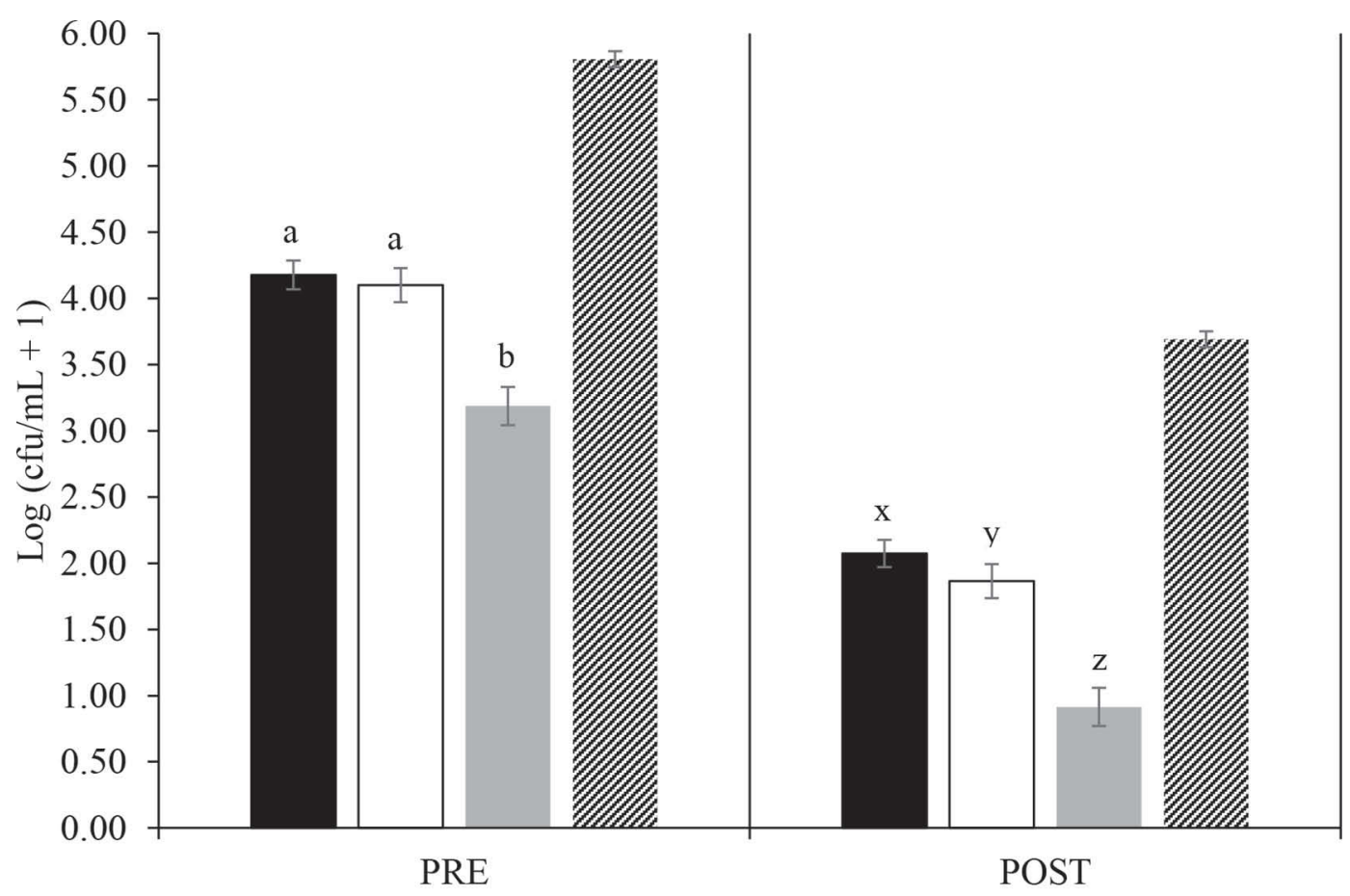

Bacterial counts

- Staph. spp. $\square$ Strep. spp. $\square \mathrm{GNB} \approx \mathrm{TBC}$

Figure 1. Overall means and 95\% confidence intervals for total bacterial count (TBC), Streptococcus spp., Staphylococcus spp., and gramnegative bacteria $(\mathrm{GNB})$ counts on teat swabs samples before $(\mathrm{PRE} ; \mathrm{n}=394)$ and after (POST; $\mathrm{n}=394)$ premilking udder preparation. Means of Streptococcus spp., Staphylococcus spp. and GNB for PRE samples with different letters (a,b) differ $(P<0.05)$; means of Streptococcus spp., Staphylococcus spp., and GNB for POST samples with different letters $(\mathrm{x}-\mathrm{z})$ differ $(P<0.05)$. Error bars indicate $95 \%$ CI. 
Table 5. Results of ANOVA models for the effect of treatment, farm, and farm by treatment interaction on reduction in total bacterial count (TBC), Streptococcus spp., Staphylococcus spp., and gram-negative bacteria (GNB) on teat skin swabs

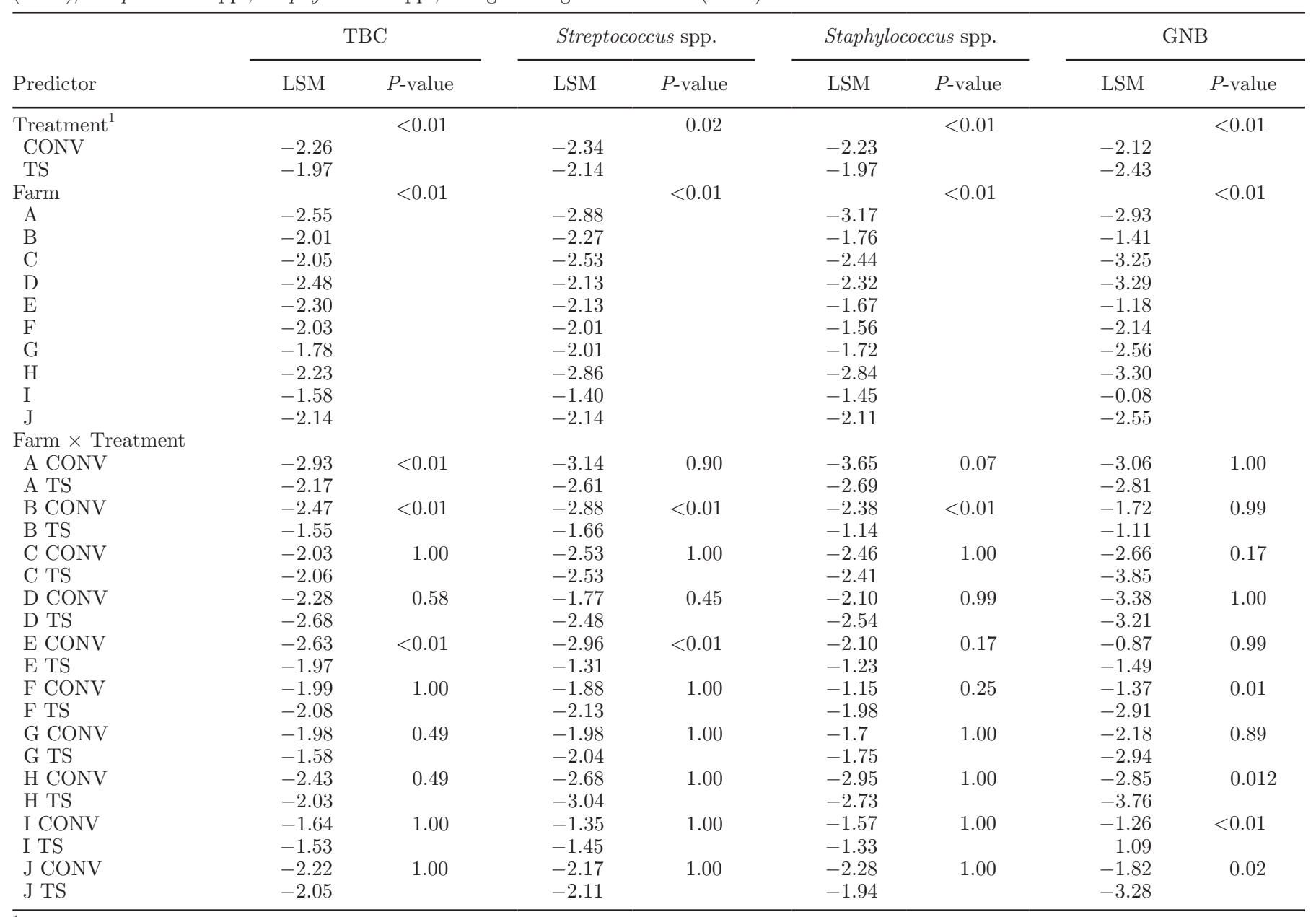

${ }^{1}$ Preparation treatments: $\mathrm{CONV}=$ conventional; $\mathrm{TS}=$ teat scrubber (FutureCOW, Longwood, FL).

have just adopted the system or herds that are using other similar technologies. Automation of the milking process in farms that have parlors is more likely to occur on larger farms. Consequently, farms enrolled in our study milked more cows and had greater milk production as compared with the typical Wisconsin dairy farm (USDA NASS, 2014). However, production and herd size were similar to a study of 51 larger Wisconsin herds (Oliveira et al., 2013; Oliveira and Ruegg, 2014), indicating that management practice of enrolled farms were characteristic of larger Wisconsin dairy farms, and it is likely that results from our study can be extrapolated to larger herds with facilities and milking procedures that are similar to those used in herds that participated in our study. Selection of farms was also designed to enroll farms that used different bedding types so that exposure to environmental pathogens would be typical of a variety of commercial farms.
Conventional methods of premilking teat sanitation are highly adopted by large Wisconsin dairy farmers (Rowbotham and Ruegg, 2015). Of 325 farms surveyed, $99.1 \%$ always applied predip, $87 \%$ always forestripped, and the majority of farms (67\%) used iodine as a predipping solution (Rowbotham and Ruegg, 2015). Of surveyed farms, about $10 \%$ were using a teat scrubber system that used chlorine dioxide as the disinfectant. Only 2 other farms $(<1 \%)$ in this data set reported use of chlorine dioxide for predipping. The TS system evaluated in our study does not use iodine; thus, when farmers purchase this TS, they are typically changing both the type of disinfectant and the method of application. The TS system evaluated in our study is not simply a different method to apply teat disinfectants, but includes an automated system for mixing and dispensing chlorine dioxide. A single mixing system supplies all of the TS units (usually there are 1 or 2 ) used 
Table 6. Results of multiple linear regression models for the effect of time spent to clean one cow (TPREP) and concentration of chlorine dioxide $(\mathrm{CD}, \mu \mathrm{L} / \mathrm{L})$ on reduction $(\mathrm{RED})$ in total bacterial count (TBC), Streptococcus spp., Staphylococcus spp., and gram-negative bacteria (GNB) counts for farms (n =10) using the teat scrubber system (FutureCOW, Longwood, FL)

\begin{tabular}{|c|c|c|c|}
\hline Predictor & $\beta^{1}$ & $\mathrm{SE}$ & $P$-value \\
\hline \multicolumn{4}{|c|}{ Model for RED in TBC $\left(R^{2}=0.56\right)$} \\
\hline Intercept & -1.6743 & 0.2710 & $<0.01$ \\
\hline TPREP & 0.0037 & 0.0228 & 0.88 \\
\hline $\mathrm{CD}(\mu \mathrm{L} / \mathrm{L})$ & -0.0009 & 0.0003 & 0.02 \\
\hline \multicolumn{4}{|c|}{ Model for RED in Strep. spp. $\left(R^{2}=0.66\right)$} \\
\hline Intercept & -1.7731 & 0.3753 & $<0.01$ \\
\hline TPREP & 0.0193 & 0.0316 & 0.56 \\
\hline $\mathrm{CD}(\mu \mathrm{L} / \mathrm{L})$ & -0.0016 & 0.0004 & $<0.01$ \\
\hline \multicolumn{4}{|c|}{ Model for RED in Staph. spp. $\left(R^{2}=0.72\right)$} \\
\hline Intercept & -1.6001 & 0.3788 & $<0.01$ \\
\hline TPREP & 0.0263 & 0.0319 & 0.43 \\
\hline $\mathrm{CD}(\mu \mathrm{L} / \mathrm{L})$ & -0.0018 & 0.0004 & $<0.01$ \\
\hline \multicolumn{4}{|c|}{ Model for RED in GNB $\left(R^{2}=0.69\right)$} \\
\hline Intercept & -1.3671 & 0.6134 & 0.06 \\
\hline TPREP & 0.0269 & 0.0516 & 0.62 \\
\hline $\mathrm{CD}(\mu \mathrm{L} / \mathrm{L})$ & -0.0033 & 0.0007 & $<0.01$ \\
\hline
\end{tabular}

${ }^{1}$ Estimated coefficient.

in the milking parlor and the concentration of the mixture delivered to the milking parlor can be modified by each farmer. No previous research has been conducted to evaluate this type of system and the objective of our study was not to compare the delivery method (manual dipping versus brushes) but to compare 2 completely

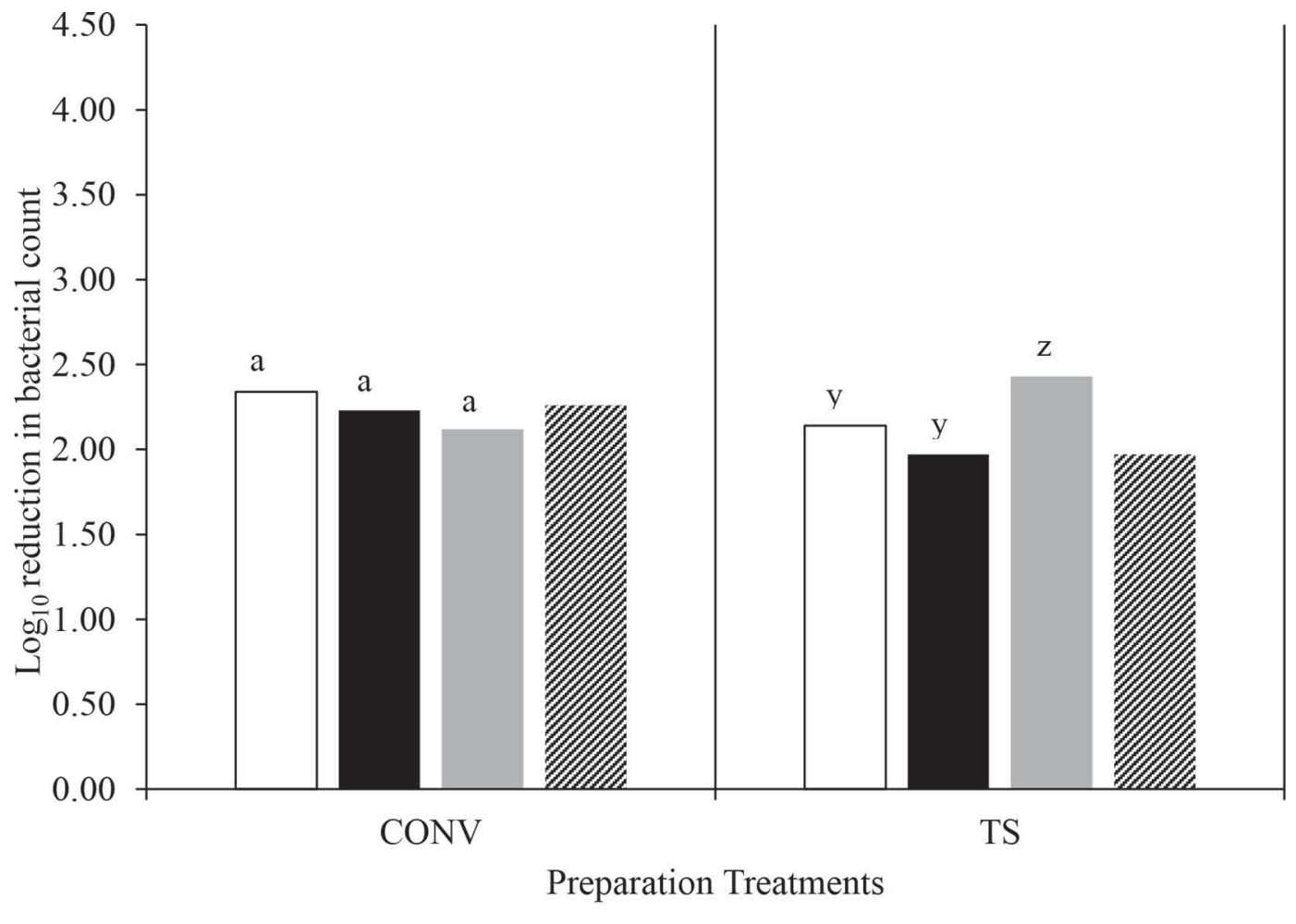

$\square$ Strep. spp. $\quad$ Staph. spp. $\quad$ GNB $\quad$ \% TBC

Figure 2. Least squares means of reduction in total bacterial count (TBC) Streptococcus spp., Staphylococcus spp., and gram-negative bacteria (GNB) on teat swabs for conventional (CONV, $\mathrm{n}=198$ ) and teat scrubber (TS, $\mathrm{n}=196$ ) premilking udder preparations. The LSM of Streptococcus spp., Staphylococcus spp., and GNB for CONV do not differ (a; P > 0.05); LSM of Streptococcus spp., Staphylococcus spp., and GNB for TS with different letters $(\mathrm{y}, \mathrm{z})$ differ $(P<0.05)$. 
different teat preparation systems. Therefore, results observed in the current study are not attributable to just the different delivery methods nor the disinfectant solution, but are a comparison of 2 completely different teat sanitation procedures.

When most farms implement this system, they change their disinfectant to chlorine dioxide and generally change their milking routine to accommodate the new system. All enrolled farms were currently using the TS, but considerable differences in milking routines were observed among farms. Recommendations for how to use the TS system have not been previously validated. The aim of our study was to compare results of using an optimized CONV routine to realistic implementation of the TS on commercial dairy farms. Thus, to evaluate the effectiveness of using this system, no modifications of the premilking procedures or concentration of chlorine dioxide were made. The TPREP, use of additional premilking procedures (such as prewipe of teats or forestripping), and the concentration of the $\mathrm{CD}$ in the TS system varied among farms, reflecting the diversity of implementation of premilking procedures. Thus, the TS treatment group included effects of both the device itself and the additional premilking procedures used on enrolled farms. The variation in methods of using the TS among farms was somewhat expected because we made no attempt to control any of the steps of the TS, and the use of the TS on commercial dairy farms is quite variable. For this reason, we assigned the same number of cows to TS and CONV within each farm and the interaction between farm and treatment was included in the models for all bacterial counts. By including farm-by-treatment interactions we were stratifying by farm, and within farm all cows cleaned using the TS were exposed to exactly the same procedures (TPREP, CD, prewipe, or not). As the results of these models show a significant farm-bytreatment interaction, only the mean comparison of the interaction terms was used to draw conclusions. The use of the TS was performed by the milking technicians according to their usual protocol and compared with a gold standard method of preparation as performed by a single university researcher. Both procedures were performed on cows that were in the milking parlor at the same time. The milking technicians knew that the TS method was being evaluated but the use of the TS system is quite standardized and the technicians were not observed to modify their routines on the animals enrolled in our study as compared with the rest of the animals in the group.

Conventional routine using an iodine solution as predipping was used as the control method because it has been demonstrated to reduce bacterial populations on teat skin (Galton et al., 1986) and the rate of new
IMI (Pankey et al., 1987; Galton et al., 1988; Oliver et al., 1993b) and is commonly used on US dairy farms (USDA, 2008). To ensure that the CONV procedure was realistic and met industry standards, premilking procedures performed by the university researcher were timed. The mean cleaning time for CONV included the time for applying the predipping solution, contact time and drying of teats, indicating that the CONV preparation was in accordance with standard milking procedures that recommend a minimum contact time of $30 \mathrm{~s}$ before drying (NMC, 2011).

Standard deviations for TPREP were compared at farm level and not at treatment level because at each farm the parlor configuration and work routine were different. Standard deviations for POST TBC were also compared at farm level because of variability in premilking bacterial load of teats. In both situations, consistency was evaluated within farm because consistency among farms could never be expected. The use of the TS unit clearly helped to standardize the teat preparation process. The variability of TPREP was greater for teats prepared using CONV in comparison to teats prepared using TS. This result was observed even though the same university researcher applied all CONV treatments on all farms, whereas different milking technicians working in different parlors applied the TS routine. No differences in variation in RED of TBC was observed between teats prepared using the TS or CONV preparation. In contrast, Bade et al. (2008) reported that standard deviations after teat preparation for viable plus dead bacteria count were larger for conventional preparation when compared with the cleaning performed by automatic milking units, indicating less consistent cleaning for manual preparation. However, as compared with automatic system units, TS is operated by a milking technician who may contribute to increased variability.

Reduced time of preparation is a point of sales for the TS and we did not modify TPREP for farms using TS that participated in our study. The time spent to clean one cow was not controlled and, therefore, TPREP was greater for CONV as compared with TS. Having controlled TPREP (by adding $30 \mathrm{~s}$ of contact time to the TS routine or omitting the $30 \mathrm{~s}$ contact time of the CONV routine), would not be realistic and would have resulted in the use of a premilking routines that is different from that used on dairy farms that have adopted the TS. Additionally, controlling TPREP would have resulted in an unfair comparison of routines in favor of the TS, as adding $30 \mathrm{~s}$ to the TS or omitting the 30 $\mathrm{s}$ contact time of the CONV routine would have likely biased the results to the benefit of the TS routine.

Cows with any sign of clinical mastitis were not eligible to enroll. The same university researcher per- 
formed the CONV routine on all farms, but the TS routine was performed by milking technicians on each farm. Although a milking technician on 8 of the farms performed forestripping, a technician on 2 of the farms did not observe foremilk from cows assigned to the TS routine, thus potentially missing the occurrence of a clinical case. To evaluate whether the failure to forestrip resulted in bias in our comparison of RED between CONV and TS, we performed a separate analysis for each bacterial count, excluding data from the farms that did not perform forestripping. The results of the analysis using the reduced data set were virtually identical to the results with the full data set; therefore, the results of the full analysis are presented in the current paper.

On each farm, both treatments were evaluated on the same day. As each farm was visited once, potential variation in RED among days could not be assessed. Environmental factors affect the degree of bacterial contamination of teat skin and day-to-day variation is therefore expected (Zdanowicz et al., 2004). However, all of the cows included in the current study were housed indoors using freestalls with consistent bedding management, so the effect of environment would be less than for animals exposed to outdoor conditions. Whereas comparisons of treatment effects would have been more robust if data had been collected over multiple days at each farm, the treatments (CONV and TS) were both evaluated the same day on each farm; thus, day-to-day variation should not have influenced the results of our study.

Teat skin condition was not evaluated in our study but researchers did not note significant abnormalities in teat skin of cows that were enrolled. However, due to the contemporaneous assignment of cows from the same groups during the same milking to either CONV or TS, differences in teat condition would not have affected one of the treatment groups in particular. Further research is necessary to evaluate whether teat skin condition has an effect on cleaning performance of the CONV and TS routine.

Most previous research about premilking teat sanitation has enrolled cows from a single dairy herd (Galton et al., 1986; Ingawa et al., 1992; Gleeson et al., 2009). Results of our study indicate that use of multiple farms improves the ability to evaluate premilking sanitation, as implemented on commercial dairy farms. Significant interactions between farm and treatment were identified, demonstrating that differing conditions on dairy farms influence the efficacy of premilking teat disinfection. Similar to our study, Gibson et al. (2008) enrolled 40 cows from each of 4 commercial dairy farms and compared 4 separate premilking sanitation methods using 10 cows/treatment per farm. However, farm and farm-by-treatment interaction were not included in the statistical model. We elected not to control for differences in how the TS was implemented among farms as we wanted to measure some of those effects and be able to arrive at recommendations for how to better use the system. The significance of treatment-by-farm interactions observed in the current study reflects the variation in implementation of management practices on commercial dairy farms and broadens the reference population for the results. Enrolling multiple farms also resulted in the unexpected finding that the concentration of chlorine dioxide varied tremendously among farms and was associated with RED. Results of our study indicate that management practices that differ among farms play an important role in the success of incorporating an automatic teat preparation system in the milking process. This conclusion could not have been drawn if the study had been conducted on a single farm.

To minimize the number of noncountable plates, the range of dilutions used in the microbiological analysis were individually determined for each bacterial count for both PRE and POST samples. Based on previous research (Rendos et al., 1975; Bramley and McKinnon, 1990; Hogan et al., 1990), greater numbers of staphylococci and streptococci were expected as compared with numbers of GNB. Likewise, greater numbers of bacteria were expected in PRE as compared with POST samples. The distribution of bacterial counts in PRE and POST samples were highly skewed due to the variability among farms in teat skin bacterial loads. The microbiological technique had lower and upper detection limits that were dependent on the range of dilutions. Bacterial counts that fell outside of detection limits truncated the distributions and contributed to a lack of normality. However, the distribution of truncated samples was homogeneous between TS and CONV for PRE samples, indicating that confounding due to differences in teat skin flora was unlikely to have influenced study results.

A variety of different outcomes have been used to evaluate efficacy of premilking udder preparations (Galton et al., 1986; Gibson et al., 2008; Gleeson et al., 2009). Galton et al. (1986) separately compared least squares means of bacteria on teat swabs collected before and after udder preparation. As no difference in bacterial counts collected before preparation was noted, the difference in least squares means after teat sanitation was assigned as a treatment effect. However, this approach could mask differences among treatments because bacterial counts after teat sanitation that do not differ among treatments could differ when they are weighted based on initial contamination of teats. Thus, including the PRE count as an explanatory variable or 
defining RED results in more powerful comparisons. In a more recent study, Gleeson et al. (2009) categorized teat skin bacterial counts based on the number of colonies recovered and defined a binary outcome (reduction in count category or not) that was analyzed using logistic regression. Although categorizing the data is an alternative for non-normally distributed variables, the difference in bacterial counts that fall in the boundaries of 2 consecutive categories could be biologically irrelevant and use of continuous data allows more precise comparisons. In agreement with Gibson et al. (2008), reduction in $\log _{10}$ bacterial counts, calculated as the difference between POST and PRE, was the outcome variable defined in the current study. This outcome is an accurate indicator of teat sanitation and met the normality assumption allowing parametric statistical analysis.

Premilking exposure of teats to environmental bacteria can occur when cows lie down on bedding and during the movement of animals to the milking parlor. Depending on the nutrients present in the bedding, different bedding materials may contain differing distributions of microorganisms and, therefore, bacterial populations on teats of cows lying on different bedding types also differ (Rendos et al., 1975; Hogan et al., 1990; Zdanowicz et al., 2004). We observed numeric differences in the distribution of Streptococcus spp., Staphylococcus spp., and GNB in different bedding types and on teats of cows bedded in these materials, but statistical significance could not be established due to small sample size ( $\mathrm{n}=10$ bedding samples). Sample size calculations for our study were based on the primary objective of determining RED of teat skin swabs. A post hoc power analysis showed that the power to detect differences in bacterial counts among bedding types was 0.32, 0.28, and 0.19 for Streptococcus spp., Staphylococcus spp., and GNB, respectively, indicating that a greater sample size would be needed to detect statistical significance at the recommended 0.80 power. Bedding type is a farm level variable and, as expected, farm level practices (such as manure management, bedding maintenance, or over-crowded housing area) can influence teat skin contamination. In our study, the purpose of enrolling multiple farms using different bedding materials was to evaluate cleaning performance of the TS system with varying levels of exposure to environmental pathogens, thus broadening the reference population.

In agreement with previous studies (Rendos et al., 1975; Hogan et al., 1990), Staphylococcus spp. and Streptococcus spp. were the most predominant bacterial types recovered from teat skin in the PRE samples, whereas GNB were less numerous. Most environmental mastitis pathogens belong to these genera; thus, pre- milking teat sanitation is an important practice that reduces potential exposure of teats to pathogens. Reducing exposure of teats to these pathogens can result in a decreased rate of new IMI and improve overall udder health (Pankey et al., 1987; Pankey, 1989). However, if premilking teat disinfection is not effective, bacterial types other than those enumerated in our study might contaminate teat skin and result in increased bacterial counts of milk. Increased bacterial counts in raw milk are associated with increased amounts of heat-resistant proteases and lipases that hydrolyze milk protein and fat, altering milk shelf life after pasteurization (Barbano et al., 2006).

Our study was designed to evaluate cow-level outcomes (teat swabs), but considerable variation in implementation of the TS was observed and use of these practices may have influenced RED. Three farms prewiped teats with a dry towel before beginning teat sanitation, 2 of those farms used $<500 \mu \mathrm{L} / \mathrm{L}$ of chlorine dioxide and 1 used $>500 \mu \mathrm{L} / \mathrm{L}$. The effect of prewiping teats before use of the TS could not be evaluated because of inadequate sample size. Further research is necessary to evaluate whether prewiping teats improves effectiveness of the TS routine.

To investigate the effect of CD and TPREP on RED, the data from just teats prepared using the TS were analyzed at farm level. Power of statistical tests using 10 observations is expected to be low and the study was not designed to specifically address herd-level management practices. The TS assessed in our study used chlorine dioxide delivered to each TS unit from a single blending system that provided each scrubber with the same concentration. The blending system combines the base (sodium chlorite), activator (lactic acid), and water to create a solution that can have the concentration adjusted at each farm. In our study, the concentration of chlorine dioxide used in the TS systems ranged from 50 to $850 \mu \mathrm{L} / \mathrm{L}$. This broad range was likely attributable to differing preferences of the farm owners, but could be due to the lack of attention to the blending system.

An effect of concentration of CD on RED of all bacterial counts was observed and RED improved as concentration of CD increased. On all farms that used $>500 \mu \mathrm{L} / \mathrm{L}$ of CD (farms C, D, H, and J), no difference in RED of TBC, Streptococcus spp., and Staphylococcus spp. was identified between CONV and TS, indicating equal efficacy for both treatments. When $<500 \mu \mathrm{L} / \mathrm{L}$ of CD was used (farms A, B, E, F, G, and I), the efficacy of RED of TBC, Streptococcus spp., and Staphylococcus spp. for TS and CONV was variable. These results suggest that the concentration of chlorine dioxide should be set at a minimum of $500 \mu \mathrm{L} / \mathrm{L}$ to maximize reduction in teat skin bacterial counts. 
Chlorine dioxide is a microbicide resulting from the combination of sodium chlorite with lactic acid and it has a broad spectrum of action against both grampositive and gram-negative bacteria (Nickerson, 2001). This compound is an oxidizing agent that destroys cellular activity of proteins (McDonnell and Russell, 1999). Likewise, iodine is a broad-spectrum microbicide that penetrate the cell wall of microorganisms and disrupt proteins, nucleotides, and fatty acids, resulting in cell death (McDonnell and Russell, 1999). Galton et al. (1986) reported no difference in TBC or coliform count of milk when the same routine was used to evaluate efficacy of chlorine-based and iodine-based sanitizers. The use of a cloth towel in the CONV treatment (compared with removal of moisture by rotating wet brushes) likely resulted in drier teats. Gibson et al. (2008) reported differences in reduction of TBC on teats that were cleaned using a chlorine-based dip (150 ppm) and a chlorine-based wash (150 ppm), suggesting that the effectiveness of a premilking udder preparation regimen is determined not only by the type of disinfectant used but also by the application method.

\section{CONCLUSIONS}

A treatment-by-farm interaction was identified for RED in TBC, Streptococcus spp., Staphylococcus spp., and GNB, indicating that management practices that differ among farms influence the effectiveness of teat disinfection using TS and CONV. For most farms, no difference in RED was observed based on method of teat sanitation. On some farms, conventional preparation using $0.5 \%$ iodine resulted in greater RED in TBC, Streptococcus spp., and Staphylococcus spp., whereas on other farms use of the TS using chlorine dioxide resulted in greater RED in GNB. For teats that were sanitized using TS, an effect of CD on RED was identified for all bacterial counts. For teats prepared using TS, reduction in bacterial counts increased as concentration of CD increased. For farms using a concentration of chlorine dioxide $>500 \mu \mathrm{L} / \mathrm{L}, \mathrm{RED}$ in TBC, Streptococcus spp., and Staphylococcus spp. did not differ between treatments. Based on this study, concentration of CD used by the TS routine should be set at a minimum of $500 \mu \mathrm{L} / \mathrm{L}$ to achieve RED in TBC, Streptococcus spp., and Staphylococcus spp. comparable to those performed by CONV. Results from this study suggest that farm conditions and additional management practices have a significant effect on effectiveness of teat disinfection.

\section{ACKNOWLEDGMENTS}

This study was financed in part by FutureCOW (Longwood, FL). We thank all dairy farmers and milk- ing technicians for participating and cooperating with this study.

\section{REFERENCES}

Bade, R. D., D. J. Reinemann, and P. D. Thompson. 2008. Method for assessing teat and udder hygiene. Paper no. 083796 in ASABE Annual International Mtg., Providence, RI.

Barbano, D. M., Y. Ma, and M. V. Santos. 2006. Influence of raw milk quality on fluid milk shelf life. J. Dairy Sci. 89:E15-E19.

Bramley, A. J., and C. H. McKinnon. 1990. The microbiology of raw milk. Pages 163-208 in Dairy Microbiology. Vol. 1. R. K. Robinson, ed. Elsevier Science Publishers, London, UK.

Elmoslemany, A. M., G. P. Keefe, I. R. Dohoo, J. J. Wichtel, H. Stryhn, and R. T. Dingwell. 2010. The association between bulk tank milk analysis for raw milk quality and on-farm management practices. Prev. Vet. Med. 95:32-40.

Galton, D. M., R. W. Adkinson, C. V. Thomas, and T. W. Smith. 1982. Effects of premilking udder preparation on environmental bacterial contamination of milk. J. Dairy Sci. 65:1540-1543.

Galton, D. M., L. G. Petersson, and W. G. Merrill. 1986. Effect of premilking udder preparation practices on bacterial counts in milk and on teats. J. Dairy Sci. 69:260-266.

Galton, D. M., L. G. Petersson, and W. G. Merrill. 1988. Evaluation of udder preparation on intramammary infections. J. Dairy Sci. 71:1417-1421.

Galton, D. M., L. G. Petersson, W. G. Merrill, D. K. Bandler, and D. E. Shuster. 1984. Effect of premilking udder preparation bacterial populations, sediments and iodine residues in milk. J. Dairy Sci. 67:2580-2589.

Gibson, H., L. A. Sinclair, C. M. Brizuela, H. L. Worton, and R. G. Protheroe. 2008. Effectiveness of selected premilking teat-cleaning regimes in reducing teat microbial load on commercial dairy farms. Lett. Appl. Microbiol. 46:295-300.

Gleeson, D., B. O'Brien, J. Flynn, E. O'Callaghan, and F. Galli. 2009 Effect of pre-milking teat preparation procedures on the microbial count on teats prior to cluster application. Ir. Vet. J. 62:461-467.

Hogan, J. S., K. L. Smith, K. H. Hoblet, D. A. Todhunter, P. S. Schoenburger, W. D. Hueston, D. E. Pritchard, G. L. Bowman, L. E. Heider, and B. L. Brockett. 1989. Bacterial counts in bedding materials used on nine commercial dairies. J. Dairy Sci. 72:250258.

Hogan, J. S., K. L. Smith, D. A. Todhunter, and P. S. Schoenberger. 1990. Bacterial counts associated with recycled newspaper bedding. J. Dairy Sci. 73:1756-1761.

Ingawa, K. H., R. W. Adkinson, and R. H. Gough. 1992. Evaluation of a gel teat cleaning and sanitizing compound for premilking hygiene. J. Dairy Sci. 75:1224-1232.

Jayarao, B. M., and D. R. Wolfgang. 2003. Bulk-tank milk analysis. A useful tool for improving milk quality and herd udder health. Vet. Clin. North Am. Food Anim. Pract. 19:75-92.

McDonnell, G., and A. D. Russell. 1999. Antiseptics and disinfectants: activity, action, and resistance. Clin. Microbiol. Rev. 12:147-179.

Murphy, S. C. 1997. Raw milk bacteria tests: Standard plate count, preliminary incubation count, lab pasteurized count and coliform count-What do they mean for your farm? Pages 34-41 in Natl. Mastitis Counc. Reg. Mtg. Proc., Syracuse, NY. Natl. Mastitis Counc., Inc., Madison, WI.

National Mastitis Council. 1995. Summary of peer-reviewed publications on efficacy of premilking and postmilking teatdisinfections published since 1980. Pages 82-92 in Natl. Mastitis Counc. Reg. Mtg. Proc., Harrisburg, PA. Natl. Mastitis Counc., Inc., Madison, WI

National Mastitis Council. 2011. Recommended mastitis control program. Natl. Mastitis Counc., Inc., Madison, WI. Accessed Mar 12, 2015. http://www.nmconline.org/docs/NMCchecklistNA.pdf.

Neave, F. K., F. H. Dodd, R. G. Kingwill, and D. R. Westgarth. 1969 Control of mastitis in the dairy herd by hygiene and management. J. Dairy Sci. 52:696-707. 
Nickerson, S. C. 2001. Choosing the best teat dip for mastitis control and milk quality. Page 43-54 in Natl. Mastitis Counc. PDPW Milk Quality Conference Proc. Madison, WI. Natl. Mastitis Counc., Inc., Madison, WI.

Oliveira, L., C. Hulland, and P. L. Ruegg. 2013. Characterization of clinical mastitis occurring in cows on 50 large dairy herds in Wisconsin. J. Dairy Sci. 96:7538-7549.

Oliveira, L., and P. L. Ruegg. 2014. Treatments of clinical mastitis occurring in cows on 51 large dairy herds in Wisconsin. J. Dairy Sci. 97:5426-5436.

Oliver, S. P., B. E. Gillespie, M. J. Lewis, S. J. Ivey, R. A. Almeida, D. A. Luther, D. L. Johnson, K. C. Lamar, H. D. Moorehead, and H. H. Dowlen. 2001. Efficacy of a new pre-milking teat disinfectant containing a phenolic combination for the prevention of mastitis. J. Dairy Sci. 84:1545-1549.

Oliver, S. P., M. J. Lewis, T. L. Ingle, B. E. Gillespie, and K. R. Matthews. 1993a. Prevention of bovine mastitis by a premilking teat disinfectant containing chlorous acid and chlorine dioxide. J. Dairy Sci. 76:287-292.

Oliver, S. P., M. J. Lewis, T. L. Ingle, B. E. Gillespie, K. R. Matthews, and H. H. Dowlen. 1993b. Premilking teat disinfection for the prevention of environmental pathogen intramammary infections. J. Food Prot. 56:852-855.

Pankey, J. W. 1989. Premilking udder hygiene. J. Dairy Sci. 72:1308 1312 .
Pankey, J. W., E. E. Wildman, P. A. Drechsler, and J. S. Hogan. 1987. Field trial evaluation of premilking teat disinfection. J. Dairy Sci. 70:867-872.

Rendos, J. J., R. J. Eberhart, and E. M. Kesler. 1975. Microbial populations of teat ends of dairy cows, and bedding materials. J. Dairy Sci. 58:1492-1500.

Rowbotham, R. F., and P. L. Ruegg. 2015. Association of bedding types with management practices and indicators of milk quality on larger Wisconsin dairy farms. J. Dairy Sci. 98:7865-7885. http:// dx.doi.org/10.3168/jds.2015-9866.

Ruegg, P. L., and I. R. Dohoo. 1997. A benefit to cost analysis of the effect of pre-milking teat hygiene on somatic cell count and intra-mammary infections in a commercial dairy herd. Can. Vet. J. 38:632-636.

USDA. 2008. Dairy 2007, Part III: Reference of Dairy Cattle Health and Management Practices in the United States, 2007 USDAAPHIS-VS, CEAH. Fort Collins, CO.

USDA NASS. 2014. Wisconsin agricultural statistics. Accessed Oct. 26 , 2014. http://www.nass.usda.gov/Statistics_by_State/Wisconsin/ Publications/Annual_Statistical_Bulletin/bulletin2014_web.pdf.

Zdanowicz, M., J. A. Shelford, C. B. Tucker, D. M. Weary, and M. A. G. von Keyserlingk. 2004. Bacterial populations on teat ends of dairy cows housed in free stalls and bedded with either sand or sawdust. J. Dairy Sci. 87:1694-1701. 